特 集 $2^{*}$

胃全摘術における脾臓合併切除の意義と適応

\begin{tabular}{|c|c|c|c|c|}
\hline \multicolumn{5}{|c|}{ 九州大学第 2 外科 } \\
\hline 杉町 & 圭蔵 & 福田＼cjkstart誠二 & 岡村 & 健 \\
\hline & 隆之 & 玉田隆一郎 & 児玉 & 好史 \\
\hline
\end{tabular}

\title{
INDICATION AND RESULTS OF SPLENECTOMY IN GASTRIC CANCER PATIENTS
}

\section{Keizo SUGIMACHI, Seiji FUKUDA, Takeshi OKAMURA, Takayuki KANEMATSU, Ryuichiro TAMADA, Yoshifumi KODAMA and Kiyoshi INOKUCHI.}

Department of Surgery II, Kyushu University, Fukuoka 812, JAPAN.

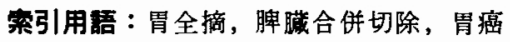

\section{はじめに}

胃全摘術においては，根治性を高めるために，摘脾が 積極的に合併されることも多いが(1)2)3)，宿主の抵抗性の 温存という観点から摘脾には消極的な意見もある4．わ れわれは胃癌の根治性を高めるという点に主眼をおき， 昭和 42 年から 47 年にかけて積極的に脾缄の合併切除を行 なったが，その遠隔成績は必ずしる期待した程の良い成 績が得られない傾向にあったので, その後は摘脾に対し て慎重な態度で臨んでいる，その間に，臨床病理学的な 検討に耐えうるかなりの胃全摘症例が集積したので, 予 後の面からこれらを分析した.

そもそも胃癌の手術に拈いては, 胃周囲のリンパ節郭 清について, 予防的郭清が有効なことは今や疑うことの ないことであるが，脾藏については予防的摘脾術の考古 を認容してよいるのであろうか. 本論文はこの点につい て重要な資料を提供するものである.

\section{I 研究対象}

昭和39年より51年までの13年間に九大第 2 外科で行な った胃全摘症例319例を摘脾の有無により表1のごとく，

* 第14回日消外総会シンポ II

進行胃癌における周用臓器合併切除の意義
表 1 胃全摘症例（昭和39年～51年）

\begin{tabular}{|c|c|c|}
\hline 摘 脾 & 症例 数 & 術死 例 \\
\hline 摘 脾 $(+)$ & $201(63.0 \%)$ & $4(2.0 \%)$ \\
\hline 脾のみ & 60 & 1 \\
\hline 脾十膵 & 122 & 3 \\
\hline 脾十荟十結腸 & 11 & \\
\hline 脾十腣十肝 & 4 & \\
\hline 脾十結腸 & 2 & \\
\hline 脾十肝 & 2 & \\
\hline 摘 脾 $($ (一) & $118(37.096)$ & $3(2.5 \%)$ \\
\hline 他の合併切除 (一) & 108 & 3 \\
\hline 結腸 & 3 & \\
\hline 肝 & 7 & \\
\hline 計 & $319(100 \%)$ & $7(2.2 \%)$ \\
\hline
\end{tabular}

摘脾 (十) 群201例と摘脾 (一) 群118例とに分けた. 年 次別に，胃全摘例における摘脾合併の実態をみると，昭 和 42 年を境として，昭和 47 年頃までは，治病，非治窟切 除を問わず，摘脾が積極的に行われていたが，それ以降 は, 脾臓の合併切除は, むしろ消極的に行われるように 
表 2 脾臟合併切除の年次推移（胃全摘）

\begin{tabular}{r|r|r|r}
\hline \hline 年 摘 $^{\text {脾 }}$ & 非摘脾 & 討 \\
\hline 昭和39 & 8 & 10 & 18 \\
\hline 40 & 17 & 8 & 25 \\
\hline 41 & 10 & 9 & 19 \\
\hline 42 & 22 & 15 & 37 \\
\hline 43 & 26 & 8 & 34 \\
\hline 44 & 21 & 3 & 24 \\
\hline 45 & 25 & 4 & 29 \\
\hline 46 & 22 & 8 & 30 \\
\hline 47 & 18 & 5 & 23 \\
\hline 48 & 7 & 17 & 24 \\
\hline 49 & 6 & 13 & 19 \\
\hline 50 & 9 & 8 & 17 \\
\hline 51 & 10 & 10 & 20 \\
\hline 計 & 201 & 118 & 319 \\
\hline & & & \\
\hline
\end{tabular}

表 3 摘脾の有無と治痹切除率

\begin{tabular}{|c|c|c|c|}
\hline 摘 脾 & 治澺切除 & 非治蕰切除 & 計 \\
\hline 摘 脾 $(+)$ & $98(49.7 \%)$ & $99(50.396)$ & $197(63.196)$ \\
\hline 朝のみ & 30 & 30 & \\
\hline 脾十苹 & 65 & 53 & \\
\hline 脾十䐙十結腸 & 2 & 9 & \\
\hline 脾十䐙十肝 & 1 & 3 & \\
\hline 脾十結腸 & 0 & 2 & \\
\hline 脾十肝 & 0 & 2 & \\
\hline 摘 脾 $(一)$ & $51(44.3 \%)$ & $64(55.796)$ & $115(36.9 \%)$ \\
\hline 合併切除 (一) & 50 & 55 & \\
\hline 結腸 & 0 & 3 & \\
\hline 肝 & 1 & 6 & \\
\hline 計 & $149(47.8 \%)$ & $163(52.296)$ & $312(100 \%)$ \\
\hline
\end{tabular}

なった（衰 2).この両群の症例の 中には，表 3 の如く 脺, 肝, 結腸など, 脾以外の㖑器を合併切除したるのる 含まれているが，本論では摘脾の有無に焦点を絞って対 比し, 術死の 7 例 (2.2\%) は検索対象から除外した。 両群の背景因子をできるだけ同じものとし，同一条件下 で両群の成績を比較するために，胃全摘312例の中から 治空切除149例を抽出した（表 3).ささらに，これらの治 疹切除例について, 癌の占居部位をみると, 表 4 のごと
表 4 治窟切除例の占居部位（胃全摘）

\begin{tabular}{|c|c|c|c|}
\hline 占居部位 & 满脾 (十) & 摛轒 $(-)$ & 計 \\
\hline Cにかかっていないもの & 11 & 17 & $28(18.8 \%)$ \\
\hline $\mathrm{AD}$ & 1 & 0 & \\
\hline$A \cdot A M$ & 3 & 11 & \\
\hline$M \cdot M A$ & 7 & 6 & \\
\hline Cにかかっているもの & 57 & 30 & $87(58.4 \%)$ \\
\hline $\mathrm{MC}$ & 13 & 8 & \\
\hline $\mathrm{C} \cdot \mathrm{CM}$ & 30 & 10 & \\
\hline $\begin{array}{l}\text { CMA } \\
\text { AMC }\end{array}$ & 14 & 12 & \\
\hline Eにかかっいるあの & 30 & 4 & $34(22.8 \%)$ \\
\hline $\mathrm{CE}$ & 30 & 4 & \\
\hline 計 & $98(65.8 \%)$ & $51(34.29)$ & $149(100 \%)$ \\
\hline
\end{tabular}

表 5 上部胃癌の深達度

\begin{tabular}{l|c|c|c}
\hline \hline 深達度 & 摘脾 $(+)$ & 摘脾 $(-)$ & 計 \\
\hline $\mathrm{ps}(-)$ & 7 & 7 & $14(16.1 \%)$ \\
\hline $\mathrm{m}$ & 0 & 2 & \\
$\mathrm{sm}$ & 2 & 2 & \\
$\mathrm{pm}$ & 2 & 1 & \\
$\mathrm{ss} \alpha, \beta$ & 3 & 2 & \\
\hline $\mathrm{ps}(+)$ & 50 & 23 & $73(83.9 \%)$ \\
\hline $\mathrm{ss} r$ & 5 & 3 & \\
$\mathrm{se}$ & 35 & 20 & \\
$\mathrm{si}$ & 10 & 0 & \\
\hline \multicolumn{1}{c|}{ 計 } & $57(65.5 \%)$ & $30(34.5 \%)$ & $87(100 \%)$ \\
\hline
\end{tabular}

く，C (上部) にかかっていないもの28例 (18.8\%), Cにかかっている の の87例 $(58.4 \%), \mathbf{E}$ (食道) にか かっているもの34例 (22.8\%) と癌占居部位は, 必ずし も一定ではなかったので，Cにかかっている87例のみを 選び出した.これら，上部胃癌で根治手術を行った87例 の深達度をみると, 变5のごとく摘脾群にのみ癌浸潤が 浆膜面をこえて直接他臓器に浸潤している si (s infiltrating）(十）10例が含まれていたので，この10例を除 いた摘脾群47例と非摘脾群30例について予後を比較検討 した.これら77例の年次別分布をみると表 6 に示すごと く，昭和 42 年から 47 年までは明らかに摘脾群が多く，48 年以降は逆に脾荿を温存した群が多くなり，摘脾の適応 が癌の進行状況により決定されたものではなく，むし ろ，摘脾に対する考方が変わったことがうかがえる. また，この77例の術者は同じであり，手術手技上の差異 はないものと考えられる. 
表 6 㭘索対象症例の年次分布

\begin{tabular}{r|c|c|c}
\hline \multicolumn{1}{|c|}{ 年 度 } & 摘 脾 & 非摘脾 & 計 \\
\hline 昭和39 & 1 & 3 & 4 \\
\hline 40 & 1 & 2 & 3 \\
\hline 41 & 2 & 5 & 7 \\
\hline 42 & 5 & 1 & 6 \\
\hline 43 & 7 & 1 & 8 \\
\hline 44 & 7 & 0 & 7 \\
\hline 45 & 6 & 1 & 7 \\
\hline 46 & 5 & 0 & 5 \\
\hline 47 & 6 & 0 & 6 \\
\hline 48 & 1 & 7 & 8 \\
\hline 49 & 2 & 4 & 6 \\
\hline 50 & 2 & 5 & 7 \\
\hline 51 & 2 & 1 & 3 \\
\hline 計 & 47 & 30 & 77 \\
\hline
\end{tabular}

予後調査に関しては，消息は77例全例判明して扰り， 生存率は胃癌取扱い規約 ${ }^{5}$ による累積生存率で示した。

$$
\text { II 成 }
$$

(1) 癌の深達度とりンパ節転移
前述の如く, 胃全摘症例のうち, 癌占居部位が C かっており，しかも，他臟器に直接浸潤のない治痖切除 例について, 癌の組織学的深達度とリンパ節転移状況を みたところ，表 7 のごとく，摘脾群では ps (-) は sm 2 例, pm 2 例, ss $\alpha, \beta 3$ 例の 合計 7 例, ps (+) は ss $\gamma 5$ 例, se 35 例の合計 40 例, 一方, 非摘脾群では ps （-）は $\mathrm{m} 2$ 例， $\mathrm{sm} 2$ 例， $\mathrm{pm} 1$ 例, $\mathrm{ss} \alpha, \beta 2$ 例の 合計 7 例, ps (t) は ss $\gamma 3$ 例, se 20 例の 合計23例で あった，次にこれらの症例のリンパ節転移状況をみる と, 摘脾群では $\mathrm{n}_{0} 21$ 例 (44.7\%), $\mathrm{n}_{1} 11$ 例 $(23.4 \%)$, $\mathrm{n}_{2}$ 14例 (29.8\%)， $\mathrm{n}_{3}$ 1 例 $(2.1 \%)$ であり，非摘脾 群では $\mathrm{n}_{0} 12$ 例 $(40.0 \%), \mathrm{n}_{1} 10$ 例 $(33.3 \%), \mathrm{n}_{2} 6$ 例 $(20.0 \%), \mathrm{n}_{3} 2$ 例 $(6.7 \%)$ と両群で注湆同じような 深達度およびリンパ節転移が認められた。

さらに，これらの症例について，脾門掞よび脾動脈幹 リンパ節転移状沉をみると，脾門リンパ節転移は摘脾群 で3/47 (6.4\%) に認められたが, 非摘脾群では脾門リ ンパ節転移例はなかった。 また，脾動脈幹りンパ節転移 は摘脾群で $4 / 47(8.5 \%)$, 非摘脾群では2/30 (6.7\%) であった。

(2) 摘脾と予後

つぎに，これら摘脾群47例，非摘脾群30例について深

表 7 深達度とリンパ節転移

\begin{tabular}{|c|c|c|c|c|c|c|c|c|c|}
\hline & 沉 诖 & 底 & 症例籹 & & 軽移り & ンパ節 & & 脾門リンパ節 & 脾動脈幹 \\
\hline & & & & $\mathrm{n}_{0}$ & $\mathrm{n}_{1}$ & $\mathrm{n}_{2}$ & $\mathrm{n}_{3}$ & 転 栘陽 性 & リンパ䬣転移陽性 \\
\hline & ps $(-)$ & $\mathrm{m}$ & 0 & & & & & & \\
\hline & & sm & 2 & 1 & 1 & & & & \\
\hline & & $\mathrm{pm}$ & 2 & & 1 & 1 & & & \\
\hline 摘 & & $\operatorname{ss} \alpha, \beta$ & 3 & 1 & & 2 & & 1 & \\
\hline & ps (+) & ss $r$ & 5 & 4 & & 1 & & 1 & \\
\hline & & se & 35 & 15 & 9 & 10 & 1 & 1 & 4 \\
\hline & & $t$ & $\begin{array}{c}47 \\
(100 \%)\end{array}$ & $\begin{array}{r}21 \\
(44.7 \%) \\
\end{array}$ & $\begin{array}{c}11 \\
(23.4 \%)\end{array}$ & $\begin{array}{c}14 \\
(29.8 \%)\end{array}$ & $(2.1 \%)$ & $\begin{array}{c}3 \\
(6.4 \%)\end{array}$ & $(8.5 \%)$ \\
\hline & ps (-) & $\mathrm{m}$ & 2 & 2 & & & & & \\
\hline & & sm & 2 & 1 & 1 & & & & \\
\hline 非 & & $\mathrm{pm}$ & 1 & & 1 & & & & \\
\hline $\begin{array}{l}\text { 挂商 } \\
\text { 椫 }\end{array}$ & & ss $\alpha, \beta$ & 2 & 1 & & 1 & & & \\
\hline 群 & ps (+) & ss $r$ & 3 & 1 & 2 & & & & \\
\hline & & se & 20 & 7 & 6 & 5 & 2 & & 2 \\
\hline & & t & $\begin{array}{c}30 \\
(100 \%)\end{array}$ & $\begin{array}{c}12 \\
(40.0 \%)\end{array}$ & $\begin{array}{c}10 \\
(33.396)\end{array}$ & $\stackrel{6}{(20.0 \%)}$ & (6.79) & 0 & $(6.796)$ \\
\hline
\end{tabular}


図 1 ps 因子と予後 (治癒切除例, si (十) を除く)
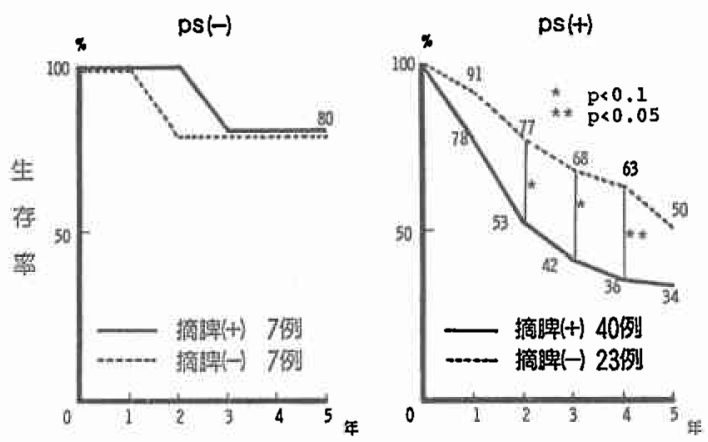

術 後 終 過 期 間

図 $2 \mathrm{n}$ 因子と予後 (治瘉切除例, si (十) を除く)

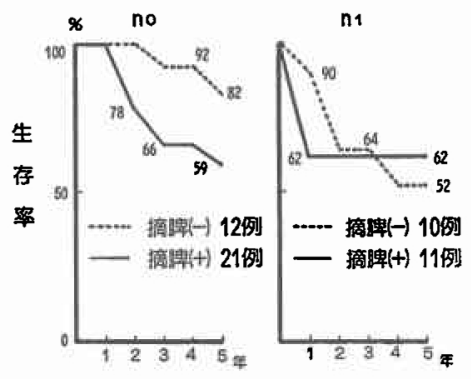

n2

誧後経過期閐

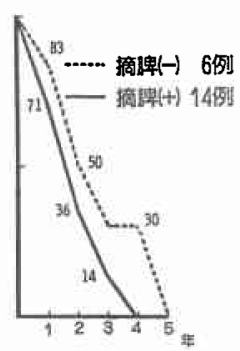

達度, リンパ節転移などの背景因子をそろえて両群の予 後を比較検討した。

まず，予後的将膜面因子 (ps) の有無で術後の生存率 を比較すると, 図1のごとく, ps (一) 例では摘脾群, 非摘脾群で，5生率はとすに80\%と予後は良好であり， 両群間で差を認めなかった。一方, ps（十）例では摘 脾群の 1 年から 5 年までの生存率はそれぞれ78，53， 42,36，34\%であるのに比べて，非摘脾群はそれぞれ $91,77,68,63,50 \%$ と 4 年生存率に於いては有意の差 $(\mathrm{p}<0.05)$ をむって脾臓を温存した群がすぐれていた。 ついで， $\mathrm{n}$ 因子別に予後を比較すると $\mathrm{n}_{0}$ 例では，摘 脾群の 1 年から 5 年までの生存率が $100,78,66,66$, $59 \%$ であるのに比べて, 非摘脾群ではそれぞれ100, $100 ， 92 ， 92 ， 82 \%$ 之非摘脾群で良い成績が得られた (図2). しかし， $\mathrm{n}_{1}$ (十) 群の 5 生率は摘脾群で62\%， 非摘脾群では $52 \%$ と両者間に有意の差を認めなかった。 一方, $\mathrm{n}_{2}(+)$ 群の摘脾群14例は, 全例 4 年以内に死亡 しており, 非摘脾群 6 例多全例 5 年以内に死亡した.

(3) 脾門リンパ節転移之予後
教室では，術中に. 脾門リンパ節転移を認める 場合に は，脾臓を合併切除することを原則としており，非摘脾 群には脾門リンパ節に転移を認めた症例はなかったが， 摘脾群 47 例中 3 例に脾門りンパ節転移を認めた. $5 ち 2$ 例は 1 年10力月括よび 2 年10カ月で死亡したが，他の 1 例は10年以上経過した現在も健在であり，少数例ではあ るが，摘脾を行い治瘾切除となった症例の中には長期生 存例があり，たと光脾門りンパ節陽性例でも，治癒切除 の可能性を持つむのであれば，より根治性の高い摘脾を 行っている.

\section{III 考察}

胃癌の手術に颃いては，根治性を高めるために拉大根

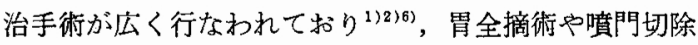
術では脾缄を合併切除するのが一般的である。しかし， 陣内“檤接浸潤，または脾門りンパ節への転移を認め ない症例に対しては，脾を脱転して脾門部リンパ節を郭 清しており，摘脾に対して慎重な態度をとっている。こ のよらに，一方では拡大手術を薦め，他方では，それに 対してやや慎重なようであるが，最も重要なことは，こ れらの治療方針が術後の遠隔成績に反映されているか否 かということであろう。

諸家の報告をみるに，金井 ${ }^{22}$ は膵体尾部切除剔脾合併 手術の意義について検討を行い，脺脾合併切除群の 5 生 率は $17.1 \%$ ，単純胃全剔出群の $10.4 \%$ に比べて良好であ ると述へ，さらに， curative resection 症例のみについ ても，前者の 5 生率は $30.4 \%$ で後者の $16.7 \%$ に比べて良 好な成績であったと報告している，しかし，この検索対 象は，昭和 26 年から 40 年までの症例であり，とくに，胃 癌取扱い規約がでさた昭和37年以前においては，必ずし む系統的なリンパ節郭清が充分に行われていないきらい もあり, 予後を比較するには合併切除の有無のみではな く, 癌占居部位, 浆膜面浸潤, リンパ節転移など癌の進 行度と共に胃切除範囲，リンパ節郭清範囲など手術に関 する因子も含めて，できるだけ同じ条件下で比較するこ とが必要であうう。また，折田”らは胃癌患者の5生率 を検討し， stage I， II では脾合併切除群(100\%, 88.9 \%)が，胃切除のみの群 $(87.1 \%, 77.1 \%)$ より良好で あり, stage III，IVでは変わらなかったと報告している が, 摘脾群の stage I 2 例, stage II 9 例と少数例での 比較であり，推計学的には差がない（stage 1, p >0.5, stage II, $0.5>\mathrm{p}>0.1$ ).

一方, 吉野 ${ }^{8}$ らは $\mathrm{A}, \mathrm{AM}$ を除く進行胃癌で，摘脾群 123例之脾温存群125例について，5生率を求めたとこ 
ろ, 前者で47\%，後者では61\%となり，有意の差をもっ て脾温存群の方が良好であったと報告し, 胃癌の根治性 を高める上で摘脾の意義はあまり大きなるのではなく， むしろ症例によっては予後を不良にする可能性が示唆さ れたと述べている．教室の成績では，治㕠切除のできた 上部胃癌で, しかも, 進行度のほ注同じ症例について比 較してみると，脾蔵を温存した方が有意の差をもってょ い成績が得られており，これは極めて興味深いことであ る.

脾葴はリンバ球の新生, 免疫抗体の産生など免疫学的 に重要な役割を有しているが, 脾缄の実験腫瑒に対する 態度は必ずしも一定しておらず, 実験尰湯の種類, 移植 時期，移植細胞数などによって時に抑制的に，時には促

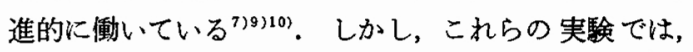
Host の条件が人胃癌の場合とは全く異っており,これ らの実験結果をるって直ちに人胃癌に扣ける摘脾につい て論じことは危険であるう，一方, 人胃癌に対する脾 臟の免疫学的意義は, 学問的にも極めて興味深いところ であり，人胃癌に類似した Host および Tumorを作製 し, しかも, 胃切除, リンパ節郭清, あるいは術後の免 疫化学療法といら臨床における一連の治療法を動物実験 で再現することにより，はじめて人胃癌に対する真の摘 脾の意義が解明されるであろう.

\section{IV まとめ}

胃全摘症例のらち癌占居部位がCにかかっており，し

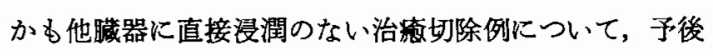
を分析し脾䁍合併切除の意義を検討し次の結論をえた.

(1) ps (十) 例の非摘脾群の $3 ， 4 ， 5$ 生率はそれぞ
れ68，63，50\%であり，摘脾群の $42 ， 36,34 \%$ に比べて とくに 4 生率で有意の差 $(p<0.05)$ をむって脾臓を温 存した群がすぐれていた.

(2) $\mathrm{n}_{0}$ 症例飞未いても，非摘脾群でややよい成績が 得られており，少なくとも脾㺃を温存することによる demerit は全く見られなかった。

\section{文献}

1) Nakayama, K.: Pancreaticosplenectomy combined with gastrectomy in cancer of the stomach. Surgery, 40: 297-310, 1956.

2) 金井弘：胃癌に対する膀体尾部切除剔脾合併 手術の意義. 日本癌治療学会誌, $2: 328-338$, 1967.

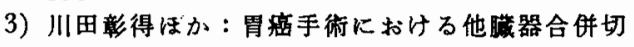
除の意義. 手術, $29: 1185-1189,1975$.

4) 陣内伝之助：胃瘦手術の適応と限界, 外科, 29: 1325-1334, 1967.

5) 胃窝取扱い规的，改訂第10版，金原出版， 1979.

6）西 满正汪か：胃癌に対する合併切除の限界飞 ついて. 手術, 26 : 882-894, 1972.

7) Orita, K., et al.: Effect of splenectomy in tumor bearing mice and gastric patients. Gann., 68: 731-736, 1977.

8）吉野一汪か：生存率から久た㵒摘の意義。日 本消化器外科学会雑誌, $12(6): 36,1979$.

9) Milas, L., et al.: The effect of splenectomy on fibrosarcoma metastases in lung of mice. Int. J. Cancer., 11: 186-190, 1973.

10) Nordlund, J. et al.: Splenic regulation of the clinical appearance of small tumors. J. Immunology, 114: 1486-1490, 1975. 